\title{
PENGAWASAN TERHADAP PENYELENGGARAAN KEKUASAAN KEHAKIMAN SEBAGAI UPAYA DALAM MEWUJUDKAN AKUNTABILITAS PERADILAN PIDANA
}

\author{
Ahmad Basuki \\ Fakultas Hukum Universitas Wijaya Kusuma Surabaya \\ e-mail: ahmadbasuki_uwks@yahoo.com
}

\begin{abstract}
ABSTRAK
Kemandirian Kekuasaan Kehakiman merupakan prasyarat yang harus dipenuhi dalam rangka bekerjanya negara hukum (materiil) atau demokratis. Negara hukum yang konsolidasi demokrasinya masih lemah menyebabkan prinsip kemandirian kekuasaan kehakiman tersebut sering disalahgunakan sehingga memicu terjadinya "mafia peradilan". Seiring dengan momentum reformasi, maka dengan mempertimbangkan pengalaman dan praktek peradilan di masa lalu, upaya pengembangan dan reformasi lembaga peradilan harus diarahkan pada administrasi peradilan yang transparan, ketat dalam pengawasan serta tegas dalam penindakan, sehingga akan mampu melahirkan lembaga peradilan yang akuntabel dan bermartabat. Kemandirian Kekuasaan Kehakiman harus diimbangi dengan prinsip akuntabilitas sebagai manifestasi sebagai negara yang demokratis.
\end{abstract}

Kata Kunci: kemandirian kekuasaan kehakiman, pengawasan dan akuntabilitas peradilan pidana.

\begin{abstract}
Judicial independence is a prerequisite that must be met in the context of the operation of democratic state. State laws which the consolidated democracies are weak could cause the independence of judicial power principle became so often misused and thus causing "judicial mafia". Along with the reformation momentum, then by considering the experience and practice of justice in the past, the development and reformation of the judiciary should be directed to the administration of justice in a transparent, rigorous oversight and resolute in action, so it will be able to bring the judiciary accountable and dignified. Judicial independence must be balanced with the accountability principle as a manifestation of a democratic state.
\end{abstract}

Keywords: Judicial Independence, Oversight and Accountability of The Criminal Justice.

\section{PENDAHULUAN}

Lembaga peradilan pidana (yang mana dalam teori Catur Wangsa terdiri atas komponen kepolisian sebagai lembaga penyelidikan dan juga penyidikan; Kejaksaan sebagai Lembaga yang berwenang untuk melakukan penuntutan; Pengadilan yang bertugas untuk memeriksa dan juga mengadili perkara; serta Lembaga Pemasyarakatan) sebagai penyelenggara kekuasaan kehakiman dilihat dalam konteks negara hukum yang demokratis merupakan lembaga yang bebas dan merdeka dari campur tangan kekuasaan negara lainnya. Prinsip ini seharusnya memberikan sandaran yang kokoh bagi lembaga peradilan untuk menyelenggarakan peradilan yang bersih, jujur dan adil.

Praktek dari mafia hukum dan peradilan yang mengemuka dewasa ini bertolakbelakang dengan prinsip independensi dari kekuasaan kehakiman. Setiap persoalan hukum yang diselesaikan melalui jalur pengadilan seolah menjadi komoditas yang diperjualbelikan, yang dapat ditawar dengan pasaran harga. Keadilan yang seyogyanya menjadi produk unggulan dari lembaga peradilan, malah yang keluar adalah putusan yang kalah-menangnya ditentukan oleh aksesibilitas dan finansial.

Bermunculannya praktek mafia peradilan terkait dengan banyak faktor penyebab, namun sekurangnya ada 3 (tiga) faktor yang utama (Sirajuddin, 2007:47), pertama menyangkut sistem rekruitmen aparat peradilan yang masih menunjukkan adanya praktek Kolusi, Korupsi dan Nepotisme (KKN) yang pada akhirnya melahirkan aparat yang tidak berkompeten, baik dari segi hardskill maupun softskill-nya; Kedua, 
menyangkut masalah transparansi pelayanan umum dan administrasi peradilan. Masalah ini penting bagi masyarakat pencari keadilan atau justiabelen, seperti menyangkut kejelasan berapa lama suatu perkara mesti di proses, berapa biaya yang dibutuhkan, serta bagaimana mekanismenya, dan lain-lain.

Berbagai keluhan masyarakat menggambarkan wajah peradilan yang birokratis dibandingkan dengan pelayanan dan kepastian hukum. Misalnya dalam tahap penyidikan perkara pidana seorang tersangka tidak mendapatkan pelayanan yang memadai, kapan perkaranya di proses dan di sidang, berapa lama dirinya akan ditahan. Bahkan begitu kuatnya dimensi kekuasaan atau birokrasi peradilan, bisa terjadi kasus penangkapan dan penahanan terhadap seseoarang yang sebenarnya tidak melakukan tindak pidana, tetapi oleh aparat dipaksakan sebagai tersangka, dan sebagai akibatnya pengadilan memutuskan terpidana terhadap orang yang tidak bersalah. Kedua persoalan yang telah dikemukakan di atas semakin diperparah dengan faktor yang ketiga, yakni lemahnya sistem pengawasan dan penindakan.

Karakteristik lembaga peradilan yang demikian rapuh, apabila dikaitkan kembali dengan independensi kekuasaan kehakiman dalam artian yang absolut, maka akan memicu untuk disalahgunakannya prinsip independensi untuk kepentingan oknum dan mafia. Sehubungan dengan hal tersebut, maka dalam rangka mengembalikan sistem peradilan pidana yang fair dan dipercaya oleh masyarakat, dipandang urgent sekali untuk melakukan pemaknaan atau penafsiran kembali konsep independensi kekuasaan kehakiman sebagaimana dimaksud dalam Undang-Undang Dasar Tahun 1945 (yang selanjutnya disebut UUD 1945) dan Undang-Undang tentang Kekuasaan Kehakiman.

Menurut Kongres Perserikatan Bangsa-Bangsa Ke-9 tahun 1995 di Kairo (Yesmil Anwar, 2011:351) bahwa dalam Sistem Peradilan Pidana terkandung prinsip Akuntabilitas, dalam arti: 1. penyelengaraan atau administrasi peradilan pidana bertanggungjawab bagi terselenggaranya peradilan pidana yang efsien dan juga manusiawi; 2. manajemen akan peradilan pidana merupakan bagian dari administrasi publik yang bertanggungjawab pada masyarakat luas; dan 3 . penyelenggaraan peradilan pidana merupakan suatu bagian dari kebijakan pembangunan sumber daya yang berkelanjutan.

Berdasarkan dari hasil Kongres PBB tersebut nampak jelas sekali, bahwasanya lembaga peradilan sebagai penyelenggara kekuasaan kehakiman yang mana bersifat independen itu berimplikasi terhadap pertanggungjawaban masyarakat luas (akuntabilitas).
Dengan demikian eksistensi akan lembaga yudikatif sebagai salah satu pilar dari negara hukum yang demokratis berkonsekuensi terhadap penyelenggaraan kekuasaan kehakiman yang tidak saja independen, tetapi juga memiliki akuntabilitas sehingga dapat menjalankan fungsi peradilan yang bersih, dipercaya oleh masyarakat dan juga menjadikannya sebagai kekuasaan kehakiman yang berwibawa.

Berdasarkan arah dan kerangka pengembangan lembaga peradilan sebagaimana yang diamanatkan oleh Perserikatan Bangsa-Bangsa (yang selanjutnya disebut PBB) tersebut, maka dalam tulisan ini dicoba untuk melakukan refleksi terhadap perkembangan kekuasaan kehakiman di Indonesia, dan juga untuk selanjutnya dapat merekonstruksi konsep kekuasaan kehakiman yang diharapkan mampu mengikis virus mafia peradilan di tubuh lembaga peradilan yang selama ini dapat dirasakan aromanya, namun sangat sulit pembuktiannya.

\section{PEMBAHASAN \\ Perkembangan Kekuasaan Kehakiman di Negara (Hukum) Indonesia}

Ketentuan dalam Pasal 1 ayat 3 UUD 1945 secara eksplisit mengemukakan bahwa. Indonesia adalah negara hukum. Apabila negara hukum itu dikaitkan dengan teori kedaulatan hukum, maka supremasi dari suatu negara tidak terletak pada kekuasaan negara, melainkan berdasarkan hukum.

Konsep kedaulatan hukum menempatkan negara harus tunduk di hadapan hukum, kedaulatan negara tunduk dan juga mengabdi pada kedaulatan hukum, karena hukum yang akan mengatur orde ketertiban masyarakat dan juga akan mengatur hubungan antara masyarakat dengan negara. Pada konteks itu, maka segala tindakan penyelenggaraan wewenang yang dimiliki oleh otoritas negara juga harus tunduk di hadapan kedaulatan hukum.

Konstitusi Indonesia juga menegaskan secara eksplisit bahwasanya kedaulatan berada di tangan rakyat, dan dilaksanakan melalui Undang-Undang Dasar. Bilamana kedaulatan hukum tersebut di atas diletakkan dan juga berpijak pada kedaulatan rakyat, maka kedaulatan hukum bukanlah ditujukan sematamata untuk kepentingan hukum itu sendiri, tetapi harus ditujukan dan berpihak kepada kepentingan masyarakat. Berkenaan dengan hal tersebut, maka penyelenggaraan suatu negara hukum harus ditujukan dan berpihak kepada kepentingan masyarakat.

Alinea ke-IV Pembukaan UUD 1945 secara jelas mengemukakan bahwa, pembentukan Pemerintahan Negara Indonesia dimaksudkan untuk melindungi 
segenap bangsa Indonesia dan seluruh tumpah darah Indonesia dan untuk memajukan kesejahteraan umum, mencerdaskan kehidupan bangsa. Ketentuan tersebut menunjukkan bahwa kedaulatan hukum berpijak pada aspirasi dan kepentingan masyarakat, hukum tidak dapat bertindak sewenang-wenang di hadapan kepentingan rakyat. Hal tersebut juga berarti bahwa, pembentukan dan penyelenggaraan pemerintahan yang diatur dalam suatu negara hukum tidak dapat mengingkari adanya suatu aspirasi rakyat, melanggar hak-hak dasar warga negaranya, dan/atau bertindak sewenang-wenang sehingga merugikan kepentingan rakyat. Kata kunci daripada ketentuan Alinea ke-IV konstitusi tersebut di atas justru ditujukan untuk tidak hanya sekedar melindungi kepentingan rakyat, tetapi negara hukum dimaksud ditujukan untuk memajukan kesejahteraan rakyat. Dalam konteks demikian, maka berarti pembentukan negara hukum bukan sebagai tujuan akhir, melainkan sebagai instrumen untuk melindungi dan mewujudkan kesejahteraan rakyat.

Salah satu komponen penting di dalam negara hukum adalah sebagaimana yang tersirat di dalam Pasal 24 ayat 1 UUD 1945, yaitu adanya kekuasaan kehakiman yang independen untuk menyelenggarakan peradilan guna mewujudkan kepastian hukum dan keadilan. Berbagai konvensi internasonal, seperti Universal Declaration of Human Rights (Article 10), International Covenant Civil and Political Rights (Article 14), International Bar Association Code of Minimum Sandart of Judicial Independent, Beijing Statement of Independent of Judiciary in the Law Asia Region juga tegaskan bahwa kekuasaan kehakiman merupakan salah satu unsur utama dalam negara hukum. Konvensi dimaksud juga mengemukakan secara lebih tegas, bahwa kekuasaan kehakiman yang dimaksud konvensi adalah kekuasaan kehakiman yang independen, tidak memihak dan kompeten.

Keberadaan akan kekuasaan kehakiman di dalam suatu negara hukum dikemukakan pula oleh mantan Ketua Mahkamah Agung ke-8, Periode 1992-1994, Purwoto Gandasoebrata, yang dengan sangat tegas mengemukakan bahwasanya konsekuensi dari negara hukum, maka merupakan Condition Sine Qua Non manakala di negara kita harus ada suatu kekuasaan kehakiman atau badan peradilan yang merdeka, dan berwibawa yang mampu menegakkan wibawa hukum, apabila terjadi pelanggaran atau sengketa hukum di dalam masyarakat (Purwoto Gandasubrata, 1998: 65).

Pada konteks Indonesia, ada periode akan sejarah penegakan hukum yang mana memperlihatkan bahwa kekuasaan kehakiman belum dapat dikualifikasikan sebagai independen. Indikasi akan adanya hal itu dapat dikemukakan dari adanya catatan sejarah sebagai berikut: Pertama, di era Kolonialisme, hakim pada Hoogerechtshof dan Raad van Justitie adalah pegawai yang terpisah dari pihak pemerintah, sedangkan ketua Landraad di Jawa dan Madura dan di sebagian luar Jawa dan Madura adalah pegawai pemerintahan yang biasanya berada di bawah Departemen Kehakiman.

Kedua, pada kurun masa Orde Lama, kekuasaan kehakiman ditempatkan sebagai alat untuk revolusi hukum untuk memenuhi rasa keadilan masyarakat, sebagaimana dinyatakan Pasal 14 dan 19 UndangUndang No. 19 Tahun 1964 mengenai KetentuanKetentuan Pokok Kekuasaan Kehakiman bahwa demi kepentingan revolusi, kehormatan negara dan bangsa atau kepentingan masyarakat yang sangat mendesak, Presiden dapat turut atau campurtangan dalam soalsoal pengadilan. Begitu pun halnya dengan otoritas dari lembaga penegakan hukum lainnya. Oleh karena itu, pada masa Orde Lama ini, Presiden menempatkan Ketua Mahkamah Agung sebagai Menteri Kabinet dengan 3 (tiga) jabatan, yaitu: Menteri Penasehat Hukum Presiden, Menteri Kehakiman, dan Menteri yang menjabat dan merangkap juga sebagai Ketua Mahkamah Agung (Philipus M. Hadjon, 1992:69).

Ketiga, pada masa Orde Baru, Presiden tidak lagi menempatkan Ketua Mahkamah Agung di bawah kekuasaan Presiden, namun syarat-syarat seorang hakim untuk dapat diangkat atau diberhentikan di atur dalam undang-undang dan di dalam perundangan dimaksud ada kewenangan dari Presiden dalam hal menentukan hakim dimaksud.

Uraian sebagaimana tersebut di atas menjelaskan dan juga memperlihatkan bahwa kekuasaan atau kepentingan eksekutif mempunyai suatu intensi untuk melakukan intervensi pada kepentingan kekuasaan kehakiman. Intervensi yang dimaksud menyebabkan kekuasaan kehakiman tidak sepenuhnya independen di hadapan kekuasaan. Pada kondisi sedemikian, maka tidaklah dapat diharapkan kekuasaan kehakiman dapat menjalankan kekuasaannya secara merdeka untuk menegakkan hukum dan juga menegakkan keadilan. Lebih-lebih di dalam kenyataannya, intervensi dari kekuasaan tersebut tidak hanya dilakukan melalui proses rekruitmen, promosi, demosi, atau mutasi saja, melainkan juga melalui kontrol organisasi dan administratif, serta politik anggaran.

Hal ini tercermin dari Pasal 7 ayat 3 Undang Undang No. 19 Tahun 1964 yang menyatakan bahwa secara teknis ada di bawah pimpinan Mahkamah Agung, namun secara organisatoris, administraif dan finansial ada di bawah kekuasaan Departemen 
Kehakiman, Departemen Agama dan departemendepartemen dalam lingkungan Angkatan Bersenjata. Dijabarkan juga hal serupa di dalam Pasal 11 ayat 1 Undang-Undang No. 14 Tahun 1970.

Mengenai politik anggaran, di dalam penjelasan pada Pasal 11 ayat 2 Undang-Undang No. 14 Tahun 1970 menyatakan bahwa, organisasi, administrasi dan keuangan tersebut terpisah dari administrasi dan keuangan departemental, walaupun demikian penentuan organisasi, administrasi dan keuangan Sekretariat Mahkamah Agung itu dilakukan oleh Pemerintah dengan bahan-bahan yang disampaian oleh Mahkamah Agung.

Berdasarkan kondisi perundangan di atas dan disertai faktor sosial politik yang melingkupi sistem kekuasaan yang ada, maka dapatlah dikemukakan bahwa negara hukum pada saat itu barulah berupa ketentuan yang bersifat tekstual karena tidak adanya dukungan dari sistem kekuasaan kehakiman yang independen. Kondisi ideal sebagai negara hukum belum dapat dicapai. Hal ini berasal dari pernyataan Ketua Mahkamah Agung yang menyatakan bahwa pada masa lalu Mahkamah Agung tidak terlepas dari intervensi institusi negara-negara yang lainnya (Bagir Manan, 2003).

Problem independensi ini merupakan salah satu masalah yang sangat fundamental dan mendapatkan sorotan yang sangat serius. Itu sebabnya, pada era reformasi persoalan independensi ini dirumuskan secara spesifik dalam konstitusi maupun perundangan yang berkaitan dengan kekuasaan kehakiman.

Secara tekstual, UUD 1945 sebelum amandemen mengatur kekuasaan kehakiman dengan menyatakan bahwa kekuasaan kehakiman dilakukan oleh sebuah Mahkamah Agung dan lain-lain Badan Kekuasaan menurut undang-undang, sedangkan syarat-syarat untuk dapat menjadi Hakim Agung dan juga untuk diberhentikan itu diatur di dalam undang-undang. Rumusan teks yang dimaksud tidak secara ekplisit menyatakan bahwa kekuasaan kehakiman adalah kekuasaan yang merdeka. Itu sebabnya, tidak ada jaminan tanpa intervensi dimaksud dapat dilakukan melalui proses pengangkatan dan pemberhentian hakim sebagaimana dimaksud di dalam Pasal 31 Undang-Undang No. 14 Tahun 1970.

UUD 1945 setelah di amandemen secara tegas mengatur kekuasaan kehakiman dengan menyatakan bahwa kekuasaan kehakiman merupakan kekuasaan yang merdeka untuk menyelenggarakan peradilan guna menegakkan hukum dan keadilan. Konstitusi dimaksud juga merumuskan secara tegas, siapa saja lembaga yang menjadi penyelenggara dan bagian dari kekuasaan kehakiman, merumuskan tugas dan wewenangnya serta hal lain yang berkaitan dengan pengangkatan dan syarat menjadi Hakim Konstitusi dan Anggota Mahkamah Yudisial.

Selain masalah independensi, Mahkamah Agung juga menghadapi masalah lainnya yang cukup serius. Mahkamah Agung juga mendapatkan sorotan yang sangat tajam berkiatan dengan integritas, kualitas dan juga kinerja dari sebagian Hakim dan Hakim Agung serta pegawai yang bekerja di Mahkamah Agung. Bermunculannya berbagai kasus suap dan juga gratifikasi di lingkungan lembaga peradilan merefleksikan fenomena mafia peradilan, sehingga dalam mereformasi lembaga peradilan tidak cukup hanya dengan menjadikan lembaga peradilan sebagai lembaga yang independen, tetapi yang lebih mendesak adalah bahwa indepedensi kekuasaan kehakiman tersebut haruslah diimbangi dengan akuntabilitas lembaga peradilan dalam melaksanakan tugas dan wewenangnya.

\section{Kekuasaan Kehakiman: Dari Independensi ke Akuntabilitas}

Purwoto Gandasubrata mengemukakan pertama kali bahwa istilah mafia peradilan dalam kerangka dan mengkaitkan agar para juris jangan berperan negativedestruktif dalam menyalahgunakan hukum sehingga memunculkan suatu tuduhan adanya mafia peradilan, penyelewengan hukum, kolusi hukum dan adanya penasehat hukum yang pinter-busuk atau advocaat in kwade zaken (Purwoto Gandasubrata, 1998:65).

Pernyataan mantan Ketua Mahkamah Agung itu dimaksudkan untuk menegaskan sinyalemen adanya mafia peradilan, kendati juga mengakui, kala itu ada peristiwa yang disebut sebagai noda-noda hitam dalam penegakan hukum dan peradilan dengan menunjuk kasus Marsinah, kasus penghinaan oleh Mahasiswa dan kasus Kredit Golden Key di Bapindo.

Selang tidak lama kemudian, terbentuklah Satuan Tugas Mafia Hukum, yaitu satuan khusus yang mana dibentuk oleh Presiden melalui Keputusan Presiden No. 37 Tahun 2010, dengan tujuan pembentuan satuan tugas itu adalah untuk mempercepat pemberantasan praktek mafia hukum yang semakin lama dianggap mengkhawatirkan dan merusak upaya penegakan hukum di Indonesia. Satgas pemberantasan mafia hukum ini mempublikasikan suatu dokumen yang berisikan modus operandi bekerjanya mafia hukum. Kata kunci mafia hukum di dalam dokumen dimaksud digunakan sebagai justifikasi bahwa kejahatan yang disebut mafia tidak hanya terjadi di berbagai tempat dan dilakukan oleh banyak pihak serta tidak hanya di 
dunia peradilan saja. Namun demikian, pada dokumen dimaksud dipetakan sekitar 79 (tujuh puluh sembilan) pola kejahatan dan sekitar 136 (seratus tiga puluh enam) modus operandi kejahatan yang khusus terjadi di dunia peradilan (Satuan Tugas Mafia Hukum, 2010).

Hal yang demikian tentu tidak hanya menyangkut tindak kejahatan yang diduga dilakukan di kalangan hakim semata, melainkan juga yang terjadi di ranah para penegak hukum yang lainnya. Fakta yang tidak terbantahkan inilah yang pertama kali, negara melalui pemerintah mengeluarkan suatu dokumen resmi yang dihasilkan dari suatu assessment yang memerinci pada tahap kejahatan, pola dan modus operandi serta pelaku kejahatan di lingkungan peradilan. Pada sisi yang lain, dokumen ini juga dapat dimaknai sebagai justifikasi pemerintah atau setidaknya satuan tugas yang dibentuk secara resmi oleh Pemerintah, atas fakta adanya suatu kejahatan yang bekerja secara massif, sistematis, dan terstruktur di lembaga hukum, termasuk institusi peradilan; dan sekaligus menolak berbagai pernyataan dari kalangan para penegak hukum yang sejak semula selalu mengingkari tuduhan adanya kejahatan yang telah bekerja secara meluas dan juga melibatkan banyak kalangan dengan modus kejahatan yang canggih.

Dalam konteks kejahatan dalam dunia peradilan, dokumen yang dimaksud telah mengidentifikasi dan memetakan potensi kejahatan sesuai dengan tahapan perkara; mulai dari tahapan pendaftaran perkara, persidangan, pembuatan putusan/penetapan, pasca putusan sampai dengan eksekusinya putusan, baik di tingkat Pengadilan Negeri, Pengadilan Tinggi, hingga di Mahkamah Agung. Dokumen yang juga mengidentifikasi para pelaku yang potensial terlibat dalam mafia hukum, yaitu: petugas registrasi perkara, panitera, panitera pengganti, hakim, ketua pengadilan, penyidik, penuntut, advokat, pelaku, maupun pihak ketiga atau calo.

Salah satu bagian penting yang mana berhasil diidentifikasi dalam kaitan dengan modus operandi kejahatan di tahap pembuatan putusan dan penetapan, dalam dokumen tersebut menyatakan sebagai berikut: Pertama, pola kejahatan dapatlah berupa negosiasi putusan atau penetapan, permintaan uang lelah atau uang terima kasih, dan penipuan; Kedua, hakim atau melalui perantara meminta uang pada salah satu pihak dengan imbalan berupa putusan perkara yang menguntungkan salah satu pihak/terdakwa/korban, mengatur besaran dari ganti rugi, memutus perkara tidak dapat diterima; Ketiga, Hakim yang menunda akan pembacaan putusan, dilelangnya amar putusan (baik dilakukan sendiri maupun dengan perantara), dilakukannya negosiasi dari putusan, dan adanya permintaan uang lelah atau terima kasih; Keempat, Salah satu pihak yang terlibat secara langsung mupun tidak langsung di dalam persidangan meminta uang dalam jumlah tertentu kepada pihak korban (terdakwa atau pihak berperkara) yaitu dengan cara menipu dan mengatasnamakan kepentingan hakim.

Uraian tersebut di atas tersebut menjadi menarik untuk dikaji lebih teliti, karena ternyata, problem kekuasaan kehakiman tidak semata-mata masalah intervensi kekuasaan eksekutif terhadap kekuasaan kehakiman, melainkan juga terkait sekali dengan problem integritas dan juga profesionalisme aparat penegakan hukum.

Intervensi dari pihak ketiga yang bukan berasal dari kalangan pemerintahan (intervensi struktural), melainkan juga dengan kekuatan kapitalnya dapat berkaitan dengan: pertimbangan hukum, alasan-alasan yang menjadi dasar justifikasi untuk membuktikan adanya suatu peristiwa hukum atau terpenuhinyatidaknya unsur dalam pasal dakwaan atau tuntutan, jumlah ganti rugi dan siapa yang bertanggungjawab. Pendeknya sangat berkaitan erat dengan hal ihwal putusan dan juga dapat dipastikan dampaknya akan sangat merugikan justiabelen atau pencari keadilan dan lembaga penegakan hukum itu sendiri.

Putusan hakim, khususnya berbagai pertimbangan hukum dan juga amar putusan adalah mahkotanya pengadilan, karena disitulah bagian yang sangatlah essensial dan juga substansial dari sebuah putusan. Kehormatan, martabat dan kewibawaan hakim dan peradilan tergantung dari apakah suatu putusan itu, khususnya bagian pertimbangan hukum dan amar putusannya telah didasarkan dan diputus berdasarkan peristiwa, fakta, doktrin, teori dan filsafat hukum serta recht idee yang berpucuk pada hukum, keadilan dalam perspektif hak asasi dan kepentingan publik.

Pada titik inilah prinsip akuntabilitas mendapatkan relevansi dan dasar justifikasi. Hakim dan peradilan seyogyanya tidaklah lagi dapat hanya semata-mata berlindung di balik prinsip independensi yang hanya untuk melindungi martabat dan kehormatannya dari potensi intervensi.

Aspek kepastian hukum dan keadilan seharusnya menjadi komplementer dari satu dan juga lainnya untuk menjamin dan memastikan agar kekuasaan kehakiman menegakkan hukum dan keadilan itu secara sungguh-sungguh dilaksanakan. Keberadaan prinsip akuntabilitas menjadi issu utama yang sangat penting sebagai mekanisme check and balances atas prinsip independensi yang dimilikinya. 
Prinsip akuntabilitas ini menjadi urgent untuk diimplementasikan karena independensi tidak dapat lagi sepenuhnya ditegakkan secara absolute, karena kekuasaan kehakiman dapat menjadi uncontrollable, yang potensial untuk digunakan melindungi perilaku koruptif daripada sebagian hakim dan/atau pihak ketiga lainnya yang mana berlindung di balik prinsip independensi.

Prinsip akuntabilitas adalah salah satu prinsip yang biasa dikenal dalam good governance system yang konsepnya dapat saja diadopsi untuk membangun sistem kerja dari institusi yudisial untuk menjadi good government judiciary system, sehingga fungsi yudisial dapat berjalan secara efektif dan efisien serta akuntabel.

Secara umum, penegakan prinsip akuntabilitas dapat dilakukan bilamana terjadi kejelasan fungsi dan pelaksanaan pertanggungjawaban dari setiap organ di dalam lembaga kekuasaan kehakiman sehingga pengelolaan kekuasaan kehakiman dapat berjalan secara efektif. Pada konteks yang demikian akan ada kesesuaian antara pengelolaan kewenangan yang didasarkan pada tugas pokok dan fungsi kekuasaan kehakiman dengan peraturan perundang-undangan yang berlaku dan prinsip-prinsip pengelolaan yudisial yang baik dan sehat.

Salah satu prinsip yang penting dalam penerapan pengelolaan yudisial yang baik adalah adanya system pengawasan, yang di dalamnya memuat rincian atas hal-hal penting yang perlu diawasi untuk menjaga martabat dan kehormatan kekuasaan kehakiman, adanya kode etik dan juga perilaku yang aplikatif, tersedianya tata cara dan juga mekanisme yang utuh dan solid, tersedianya orang-orang yang memiliki profesionalitas dan juga integritas dalam melakukan pengawasan.

\section{Pengawasan: Upaya Mewujudkan Akuntabilitas Peradilan Pidana}

Di dalam tulisan yang membahas soal krisis yang terjadi di dalam pemerintahan disebutkan ada 3 (tiga) yang menjadi faktor penyebab krisis pemerintahan yaitu: Pertama, rendahnya kompetensi dan integritas pejabat dan/atau pegawai di lingkungan birokrasi pemerintahan sehingga birokrasi menjadi tidak efektif dan efisien; Kedua, di sub-ordinasikannya institusi hukum, lembaga pelayanan publik dan biroktrasi oleh elit kekuasaan dan pejabat pemerintahan di berbagai tingkatan sehingga tidak ada kepastian hukum, biaya pelayanan menjadi tinggi dan bersifat diskriminatif; Ketiga, adanya sikap dan perilaku koruptif yang mana berkembang di dalam lingkungan aparatur dan birokrasi institusi di dalam menjalankan tugas dan kewenangannya (Bambang Wijoyanto, 2003:197).

Uraian di atas menunjukkan bahwa krisis lembaga pemerintahan terkait dengan problem profesionalitas, integritas, independensi dan akuntabilitas. Apabila sinyalemen di atas diproyeksikan terhadap lembaga yudisial, maka potensi terjadinya krisis peradilan pun juga sangat terbuka kemungkinannya. Oleh karena itu, salah satu upaya preventif yang dapat dilakukan untuk mencegah terjadinya krisis peradilan adalah penguatan akan pengawasan terhadap setiap bentuk penyelenggaraan wewenang dan diskresi aparatur penegakan hukum.

Dalam perspektif teori, konsep akan pengawasan dikembangkan di dalam ilmu manajemen, karena pengawasan itu merupakan salah satu unsur dalam kegiatan pengelolaan (manajemen). Henry Fayol menyebutkan bahwa control consist in veryvying wether everything occured in conformity with the plan adopted, the instruction issued and principle established. It has for object to point out weaknesses in error in order to rectivy then and prevent recurrence (Muchsan, 2000:37). Sejalan dengan Henry Fayol, Newman berpendapat bahwa control is assurance that the performance conform to plan (Muchsan, 2000: 37). Selanjutnya Muchsan mengemukakan bahwa pengawasan adalah kegiatan untuk menilai suatu pelaksanaan tugas secara de facto, sedangkan tujuan pengawasan hanya terbatas pada pencocokan apakah kegiatan yang dilaksanakan telah sesuai dengan tolok ukur yang telah ditetapkan sebelumnya (dalam hal ini berupa rencana atau plan) (Muchsan, 2000:37). Sedangkan Bagir Manan memandang kontrol sebagai sebuah fungsi sekaligus hak, sehingga lazim disebut fungsi kontrol atau hak kontrol. Kontrol mengandung dimensi pengawasan dan pengendalian. Pengawasan yang bertalian dengan arahan atau directive (Bagir Manan, 2001:201).

Berdasarkan beberapa pendapat tersebut, maka dapat diperoleh makna dasar dari pengawasan adalah: 1. Pengawasan ditujukan sebagai upaya pengelolaan untuk mencapai hasil dari tujuan; 2. Adanya tolok ukur yang dipakai sebagai acuan keberhasilan; 3 . Adanya kegiatan untuk mencocokkan antara hasil yang dicapai dengan tolok ukur yang telah ditetapkan; 4. Mencegah terjadinya kekeliruan dan menunjukkan cara dan tujuan yang benar; dan 5. Adanya tindakan koreksi apabila hasil yang dicapai tidak sesuai dengan tolok ukur yang ditetapkan (Irfan Fachrudin, 2004: 90).

Dalam kerangka tindakan pengawasan, ada begitu banyak lembaga yang melakukan pengawasan dan 
memfungsikan diri sebagai lembaga pengawasan. Paulus Effendi Lotulung memetakan suatu lembaga pengawasan sebagai berikut (Paulus Effendi Lotulung 1993): Pertama, ditinjau dari segi kedudukan dari badan atau organ yang melaksanakan kontrol; dapat dibedakan atas: 1 . Kontrol intern atau built in control, berarti pengawasan yang dilakukan oleh organisasi atau structural masih termasuk dalam lingkungan pemerintah sendiri; 2. Kontrol eksternal, pengawasan yang dilakukan oleh organ atau lembaga-lembaga yang secara organisasi atau structural berada di luar pemerintah.

Kedua, ditinjau dari segi waktu pelaksanaanya suatu kontrol dapat dibedakan menjadi: 1. Kontrol a priori, yaitu pengawasan yang dilakukan sebelum dikeluarkannya peraturan perundang-undangan yang memberikan kewenangan pengawasan kepadanya; 2. Kontrol a poteriori, yakni pengawasan yang baru terjadi sesudah dikeluarkan peraturan perundangan atau sesudah terjadinya tindakan atau peristiwa yang akan dikontrol.

Ketiga, ditinjau dari segi obyek yang diawasi, maka kontrol dapat dibedakan antara: 1 . Kontrol segi hukum, adalah kontrol untuk menilai segi-segi pertimbangan yang bersifat hukum dari tindakan pemerintah; 2. Kontrol dari segi kemanfaatan, adalah untuk menilai tepat tidaknya tindakan pemerintah dilihat dari segi pertimbangan kemanfaatannya.

Secara umum sistem pemerintahan di Indonesia, tindakan pengawasan itu dapatlah dilakukan secara internal maupun eksternal (Galang Asmara, 2005: 126). Pengawasan eksternal dilakukan oleh lembagalembaga negara seperti Dewan Perwakilan Rakyat, Badan Pemeriksa Keuangan, Mahkamah Agung dan lembaga-lembaga peradilan di bawahnya, termasuk dalam kategori kontrol eksternal adalah pengawasan yang dilakukan oleh orang-perorangan, kelompok masyarakat, Lembaga Swadaya Masyarakat (LSM) dan media massa. Sedangkan pengawasan internal dapat dilakukan oleh lembaga yang dibuat secara khusus oleh pemerintah sendiri, seperti halnya Badan Pengawas Keuangan Pembangunan, Pengawasan oleh Inspektorat Jenderal yang ada di lingkungan departemen, Badan Pengawasan Daerah.

Disamping berlaku pengawasan secara umum sebagaimana disebutkan di atas, khusus berkaitan dengan kekuasaan kehakiman itu juga dilakukan pengawasan-pengawasan khusus, yaitu pengawasan yang dilakukan oleh pihak Komisi Yudisial, Komisi Kejaksaan, dan Komisi Kepolisian yang kesemuanya dimaksudkan untuk melakukan pengawasan terhadap perlaku aparat penegak hukum guna mengawasi dan menegakkkan kehormatan dan keluhuran martabat, serta menjaga perilaku aparat dalam melaksanakan tugas dan wewenangnya.

Dalam rangka membangun sistem pengawasan yang akuntabel, maka ada beberapa langkah yang mana perlu mendapatkan perhatian serius (Bambang Wijoyanto, 2010:143-144). Pada tahap pertama, perlu didorong suatu keterbukaan dalam menjalankan dan mengemukakan informasi yang bersifat material dan relevan atau disclousure, mengenai lembaga dalam melaksanakan tugas dan wewenangnya. Informasi dimaksud haruslah bersifat akurat dan juga aktual mengenai kinerja dari institusi kepada justiabelen.

Pada tahapan yang kedua, upaya-upaya untuk memastikan akan adanya independensi perlu terus dilakukan. Independensi tetap merupakan salah satu prinsip yang sangat penting karena harus dimaknai sebagai keadaan dimana kekuasaan kehakiman itu tidak hanya dibebasan dari intervensi kekuasaan saja, namun juga semua faktor, pengaruh atau juga tekanan pihak lainnya yang bertentangan dengan integritas dan juga kredibilitas kekuasaan kehakiman yang baik. Pendeknya, institusi seyogyanya tidak mendapatkan tekanan di dalam menjalankan tugas dan kewenangannya dari dalam maupun luar institusi, baik berupa faktor capital maupun non capital.

Selain masalah transparansi dan independensi, ada juga syarat penting lainnya untuk mewujudkan tanggungjawab dari institusi, yaitu: adanya indikator dan parameter yang terukur serta mekanisme yang jelas untuk mengukur kinerja lembaga dan aparatur yang bekerja pada institusi kekuasaan kehakiman. Upaya untuk mewujudkan akuntabilitas yang baik, biasanya ada suatu program atau didahului dengan suatu proyek yang diarahkan pada pelaksanaan atau aktualisasi daripada prinsip transparansi; atau bisa juga terjadi, atau setidaknya kedua transparasi dan akuntabilitas diterapkan bersamaan, karena tidak akan ada akuntabilitas tanpa adanya transparansi. Kedua prinsip dimaksud dapat diletakkan sebagai bagian untuk membangun sebuah sistem saling imbang dan saling mengontrol atau check and balances system.

Pada konteks pengawasan, penerapan sistem yang dimaksud secara konsisten dapat menjadi bagian dari upaya pencegahan korupsi karena penggunaan suatu kewenangan senantiasa harus dilakukan secara transparan sehingga dapat lebih mudah terdeteksi dan diantisipasi jika digunakan tidak sesuai dengan maksud dan tujuan pemberian wewenang tersebut. Akuntabilitas pengawasan dapat dilakukan bilamana penggunaan kewenangan yang melekat pada tugas pokok itu dilakukan secara transparan. 


\section{PENUTUP}

\section{Kesimpulan}

Hasil survey dari berbagai lembaga independen yang menempatkan peradilan di Indonesia sebagai lembaga peradilan yang terburuk di tingkat Asia merefleksikan problem yang serius dalam penegakan hukum di Indonesia. Bahkan hasil survey tersebut diperkuat dengan mafia peradilan sebagaimana yang dijelaskan dalam hasil assessment yang dilakukan oleh Satuan Tugas Mafia Peradilan.

Mafia peradilan yang mewabah di lingkungan kekuasaan kehakiman tidak dapat dilepaskan dari lemahnya suatu sistem pengawasan internal lembaga, tidak terkonsolidasiya sistem pengawasan internal dan eksternal, tidak terintegrasinya pengawasan melekat dan pengawasan fungsional, tidak diakomodirnya partisipasi publik melalui penanganan klaim dan komplain maupun kontribusi ide dan gagasan untuk turut serta menjaga martabat dan juga penghormatan kekuasaan kehakiman, lemahnya karakter dan juga integritas hakim dan unsur pimpinan lembaga dan masih tertutupnya sistem dan prosedur operasional penyelenggaraan kekuasaan kehakiman.

Berbagai kelemahan tersebut seharusnya menjadi pijakan bagi semua komponen dari bangsa sebagai pemangku kepentingan atau disebut stakeholders dalam rangka melakukan reformasi kelembagaan ke arah kekuasaan kehakiman yang lebih independen dan akuntabel untuk mewujudkan peradilan yang bersih, terpercaya dan juga berwibawa, sebagaimana yang diamanatkan oleh konstitusi.

\section{Rekomendasi}

Perlunya reformasi kelembagaan dari kekuasaan kehakiman agar dapat tercapai peradilan yang bersih, terpercaya dan berwibawa.

\section{DAFTAR PUSTAKA}

\section{Buku:}

Anwar, Yesmil, et.al., 2011, Sistem Peradilan Pidana, Konsep, Komponen dan Pelaksanaannya dalam Penegakan Hukum di Indonesia, Bandung: Widya Padjadjaran

Asmara, Galang, 2005, Ombudsman Nasional dalam Sistem Pemerintahan Negara Republik Indonesia, Yogyakarta: Leksbang Pressindo.
Fachruddin, Irfan, 2004, Pengawasan Peradilan Administrasi terhadap Tindakan Pemerintah, Bandung: Alumni.

Gandasubrata, Purwoto, 1998, Renungan Hukum, Ikatan Hakim Indonesia.

Hadjon, Philipus M., 1992, Lembaga Tertinggi Negara dan Lembaga-lembaga Tinggi Negara sesuai Undang-Undang Dasar 1945: Suatu Analisa Hukum dan Kenegaraan, Surabaya: Bina Ilmu.

Komisi Yudisial Republik Indonesia, 2010, Reformasi Peradilan dan Tanggung Jawab Negara, Jakarta: Komisi Yudisial RI.

Lotulung, Paulus Efendi, 1993, Beberapa Sistem tentang Kontrol Segi Hukum terhadap Pemerintah, Bandung: Citra Aditya Bahkti.

Manan, Bagir, 2003, Cetak Biru Pembaruan Mahkmah Agung, Jakarta: Mahkamah Agung RI. , 2001, Menyongsong Fajar Otonomi Daerah, Yogyakarta: Pusat Studi Hukum FH UII, 2001,

Muchsan, 2000, Sistem Pengawaan terhadap Perbuatan Aparat Pemerintah dan PTUN di Indonesia, Yogyakarta: Liberty.

Muhammad, Abdulkadir, 2012, Hukum Acara Perdata Indonesia, Jakarta: Citra Aditya Bakti.

Satuan Tugas Mafia Hukum, 2010, Mafia Hukum: Modus Operandi dan Permasalahan dan Strategi Penanggulangannya, Jakarta.

Sirajuddin, et.al., 2007, Komisi Pengawas Penegak Hukum, Mampukah Membawa Perubahan, Malang: Malang Corruption Watch (MCW)YAPPIKA.

Wijoyanto, Bambang, 2003, Disertasi, Pencegahan Korupsi Melalui Penerapan Tata Kelola Perusahaan yang Baik dalam Badan Usaha Negara dihubungkan dengan Konvensi PBB Anti Korupsi.

\section{Peraturan Perundang-Undangan:}

Undang-Undang Dasar 1945.

Undang-Undang No. 19 Tahun 1964 tentang Ketentuan-Ketentuan Pokok Kekuasaan Kehakiman.

Undang-Undang No. 14 tahun 1970 tentang Ketentuan-ketentuan Pokok Kehakiman.

Universal Declaration of Human Rights.

Universal Covenant Civil and Political Rights. 